"Internal business process performance of the Nepalese telecom industry"

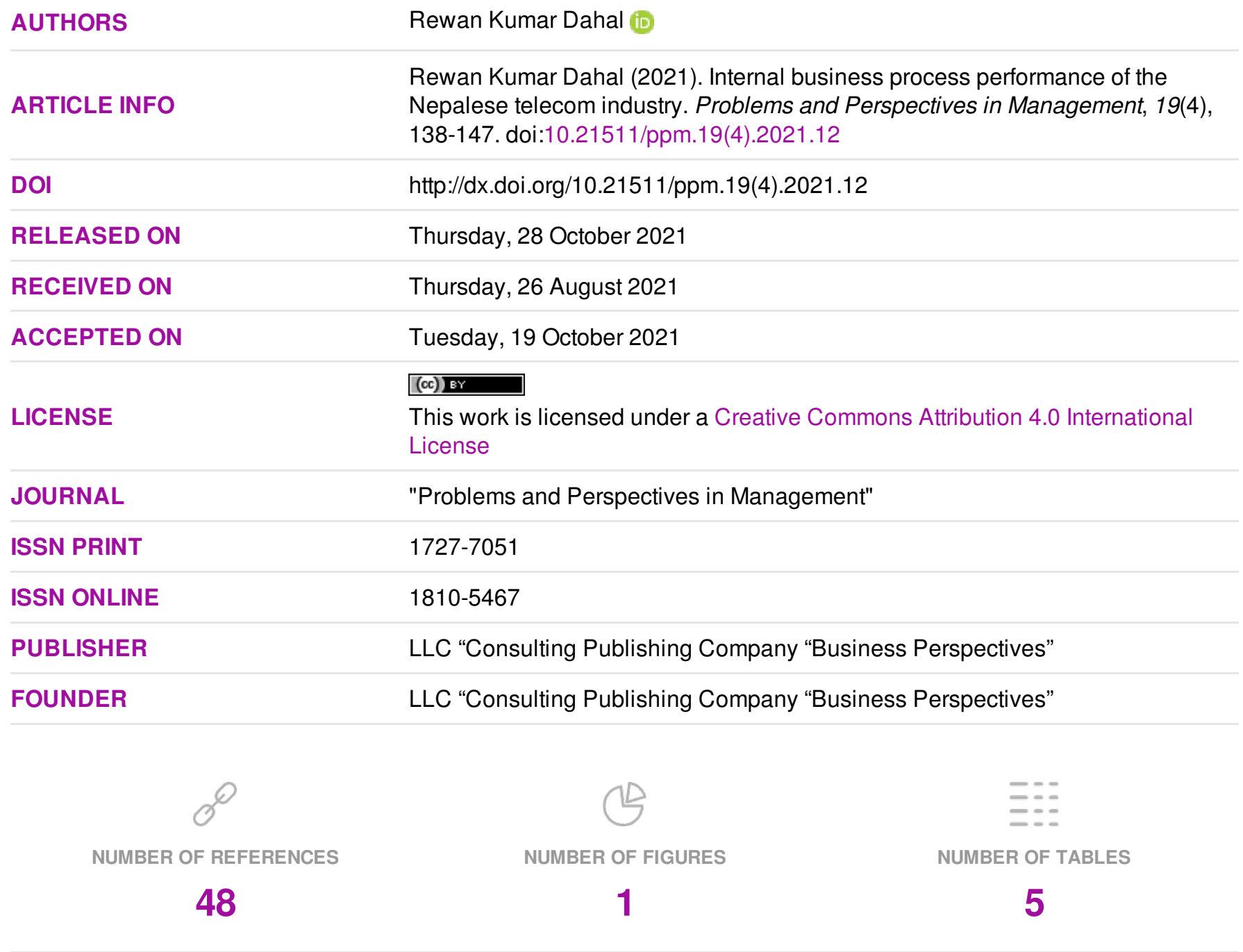

C The author(s) 2021. This publication is an open access article. 


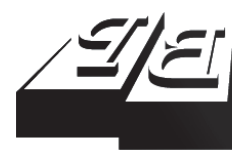

\section{BUSINESS PERSPECTIVES}

LLC "CPC "Business Perspectives" Hryhorii Skovoroda lane, 10, Sumy, 40022, Ukraine www.businessperspectives.org
Received on: $26^{\text {th }}$ of August, 2021 Accepted on: $19^{\text {th }}$ of October, 2021 Published on: $28^{\text {th }}$ of October, 2021

๑) Rewan Kumar Dahal, 2021

Rewan Kumar Dahal, Ph.D. Scholar, Assistant Professor, Faculty of Management, Nepal Commerce Campus, Tribhuvan University, Nepal.

Rewan Kumar Dahal (Nepal)

\title{
INTERNAL BUSINESS PROCESS PERFORMANCE OF THE NEPALESE TELECOM INDUSTRY
}

\begin{abstract}
The study looked at the use of internal business process metrics within the performance assessment framework of the Nepalese telecom industry. It employed a descriptive study approach and an organized questionnaire survey instrument. The population of this study included all of Nepal's telecom operators and their employees. The sample organizations from which random sampling techniques obtained the responses of 318 employees were Nepal Telecom and Ncell. The employees who hold at least offers and above positions at their company were the targeted respondents of the study. Three parts of the survey questionnaire were set up with 27 questions of different types to gather data. SPSS (statistical package for social sciences) program was employed to process and analyze the data. Sixteen measuring variables within four constructs were examined to assess the IBPP (internal business process performance). Three of these constructs: operations management $(\beta=0.229, \mathrm{p}<0.01)$, customer management $(\beta=0.380, p<0.01)$, and regulatory and social processes $(\beta=0.175, \mathrm{p}<0.01)$ were found to have a statistically significant and favorable impact on the IBPP while innovation processes $(\beta=0.024, \mathrm{p}>0.05)$ was not properly applied and understood in the Nepalese telecom industry. The findings of this study will help identify the primary drivers of performance metrics and their relevance in organizational performance for the Nepalese telecom industry.
\end{abstract}

Keywords

JEL Classification

\section{INTRODUCTION}

The performance measurement framework is a set of indicators that enable organizations to adequately and proficiently accomplish their objectives (Ahmad \& Zabri, 2016). It is an assortment of processes that an association uses to monitor its strategy execution, convey its status and achievement, and influence its stakeholders' attitudes and activities (Franco-Santos et al., 2007). The performance measurement system reflects the fundamental lens through which individuals 'see' their association performance. The biggest challenge of modern business organizations is breaking a fundamental rule of performance measurement. The truth is that even though the majority of the company has become too sophisticated, performance metrics and measuring systems remain a stronghold of conventional thought. The significant issue with performance measurement is that the environment has changed; however, performance measurement has remained almost the same (Spitzer, 2007). Many existing measures seriously restrict performance and prevent changes in a breakthrough performance, especially in knowledge work and services industries (Kaplan \& Norton, 2001).

Various success metrics and assessment methods can transform how individuals perceive their work, products, and customers in organizations. Several businesses have sought to reinvent themselves by implementing short-term strategies and improvements in superficial pro- 
cesses, systems, or technology without making any substantial adjustment to the way people see their organizations and their way of organizations (Dotzel et al., 2013; Farooq \& Hussain, 2011; Kaplan \& Norton, 2001; Selvam et al., 2016). Organizational transformation does not entail a significant shift in organizational structure or processes, but only how to assess the organization, including modifying the current performance assessment framework (Spitzer, 2007). Out of various transformation steps, this study concentrated on the performance measures of internal business processes becoming an integral type of corporate disclosure. The assessments focus on an organization's activities that delight its customers and achieve excellence through continuous process improvements.

Throughout the past few years, analysts and practitioners have emphasized the importance of going beyond financial indicators to incorporate a greater range of non-financial indicators into an organization's performance reporting. Thus, the study focuses on non-financial measures based on internal business process measurement for the Nepalese telecommunications industry since it is an essential means of productivity in economies and societies. The industry contributes significantly to countries' economic activities and other sectors' development (Venkatram \& Zhu, 2012).

Liberalization of Nepal's telecom sector has improved accessibility, availability, and reliability in the quality and services through private sector participation. Five telecom operators (Nepal Telecom, Ncell, Smartcell, Hellonepal, and United Telecom Limited) with a wide range of technologies provide services in Nepal. Nepal Telecom (NT) is a public corporation with over 91 percent holding of the Government of Nepal, while others are private companies. As per the Nepal Telecommunication Authority (2020) Report, NT (46.91\%) and Ncell (47.30\%) captured more than 94 percent of the Nepalese Global System for Mobile (GSM) market. In such a scenario, this effort concentrates on applying internal business processes in performance measurement of the Nepalese telecom industry, taking as a sample of two major players: NT and Ncell.

In general, Nepalese organizations failed to realize the real power of measurement. Therefore, the study proposed a subjective view of performance measurement through a new lens and tried to find the answer: (i) what is the internal business process performance? (ii) why are they needed in organizational performance measurement systems? And (iii) how do they affect organizational performance?

Measurement is probably one of every organization's highest leverage practices. When most people think about measurement, they think about its technical components, such as data collection, processing, statistical calculations, analysis, etc. However, success assessment by incorporating non-financial measures is far more than number and scorecard tables. Numbers are used in measurement, but it is not about numbers. It is about perception, comprehension, and interpretation (Spitzer, 2007). If a measurement is done effectively and correctly, it can have a significant positive and transformative impact on its overall performance. The purpose of the study was to observe the effectiveness of internal business process measures in the Nepalese telecommunications industry and aimed to (i) examine the applicability of internal business process in performance assessment systems; (ii) access important internal business process performance indicators; and (iii) evaluate the power of internal business processes.

The performance assessment systems focused on financial metrics performed well in the industrial era. Nevertheless, today, systems are out of line with businesses' expertise and skills (Kaplan \& Norton, 1992). When Kaplan and Norton (1993) analyzed three organizations' overall performance using a balanced scorecard, this was the cornerstone of non-financial performance metrics in an organizational performance measuring framework (e.g., internal business processes, consumers, learning and growth, etc.). Non-financial performance indicators have attracted increased attention from modern business organizations in recent years as a means of providing managers with more knowledge and insights (Ahmad \& Zabri, 2016). In the context of information technology-based services, non-financial performance indicators such as IBPP are significant, even though their everyday activities are more challenging than those of any other type of association. 


\section{LITERATURE REVIEW AND HYPOTHESES DEVELOPMENT}

ICTs (information and communications technologies) have transformed the ways of today's businesses courses. In the telecommunication industry, the benefit of ICTs has been evaluated by how they can expand intangible assets like improve response quality and timeliness, service customization, and relationship management (Josee et al., 2016). Information systems used to evaluate individual and organizational capabilities are called corporate performance measurement systems (Zuriekat et al., 2011). These systems are critical sources of information about financial outcomes and internal processes (Yeniyurt, 2003).

Amir and Lev (1996) examined the effectiveness of non-financial metrics in wireless communication businesses. They noticed that significant investments were made in intangibles like research and development, customer acquisition, franchise development, and brand development to ensure the smooth operations of the businesses. Technology and communication have historically been allied with considerable advancements, which has resulted in the telecommunications business experiencing a growth pattern that is distinct from that of other industries (Khanmohammadi et al., 2015). As a result, technological advancements have emerged as a strategic resource for telecommunications companies to improve efficiency, controlling operations, productivity, and profitability (Josee et al., 2016).

The internal business process interventions allow managers to recognize essential processes for achieving customer and stakeholder goals (Kaplan \& Norton, 2001). The internal processes' primary concern is to enhance order management, distribution, production of goods, serving consumers satisfactorily, and increase return on investment (Farooq \& Hussain, 2011). Atkinson et al. (2014) categorized the internal process measures as (i) operations management processes (OMPs) that improve asset efficiency and supply chain management; (ii) customer management processes (CMPs) that monitor the process of customer value enhancement and include selection, acquisi- tion, retention, and growth; (iii) innovation processes (IPs) that demonstrate the process of delivering new goods and services; and (iv) regulatory and social processes (RSPs) which concerns with the environment, health and safety, employment practices and community investment. Such initiatives incorporate internal business practices to ensure that the goods and services provided by businesses meet the needs of their customers and other stakeholders.

OMPs are the basic set of daily operations that take inputs, generate outputs, and provide customers (Silver, 2004). It is about getting things done effectively and efficiently in organizations. Studies showed that measures like assets utilization (Majumdar, 1998), excellence in processes (Muazu \& Tasmin, 2017), superior supplier capabilities (Flint et al., 2002; Scheer et al., 2010), better customer service (Joshi, 2014), business process reengineering (Khashman, 2019; Mukherjee \& Chatterjee, 2013), time-based competition (Hum \& Sim, 1996; Sapkauskiene \& Leitoniene, 2010), etc., are applicable in the telecom industry to assess the OMPs performance. CMPs broaden and deepen customer relationships (Kaplan \& Norton, 2001). The processes analyze and improve customer-centric issues to gain effectiveness and efficiency within an organization. Based on the literature, the measures of the processes are acquiring new customers (Min et al., 2016), satisfying and retaining existing customers (Ali et al., 2010; Ndubisi, 2003), generating growth with customers (Kaplan \& Norton, 1996; Ndubisi, 2003), etc.

IPs produce innovative products, processes, and services, helping the business enter new markets and customer segments. Practical innovation drives customer acquisition, loyalty, and growth, leading to increased operating margins (Kaplan \& Norton, 2001; Kyei \& Bayoh, 2017). It may be incremental changes to existing goods, making breakthroughs such as entirely new products and services, lowering prices, improving performance, new business models, new projects, and many other types (Morris, 2013). According to previous studies, some of the IPs measures in the telecommunications industry are: designing innovative products and services (Kyei \& Bayoh, 2017), achieving outstanding research and development processes (Kaplan \& Norton, 2001), handling the 
research and development portfolio (Cooper et al., 1998; Kaplan \& Norton, 2001), etc. The reputation for excellence in RSPs helps businesses recruit and retain high-quality staff. Managing and reporting on regulatory and social success across a range of crucial dimensions such as environment, employees' health and safety, employment practices, community investment, etc., is essential (Atkinson et al., 2014; Kaplan \& Norton, 2001).

A performance assessment framework is used to measure institutional activities' efficiency and efficacy to understand design and usage factors better. Diverse internal and external environmental factors affect organizational performance assessment. Measuring business process efficiency includes controlling whole chains of institutional actions that eventually add value to its customers. An organization can do more with its existing resources through efficient business processes to increase productivity (Sullivan, 2001). Academic researchers have noted a strong association between business process efficiency and organizational performance. Such a relationship has been observed either as a causal relationship (Melville et al., 2004) or as distinct coexisting indicators (Kaplan \& Norton, 1996). The IBPP model is depicted in Figure 1 as a systemic representation.

Equation 1 described a regression model based on the framework for IBPP:

$$
\begin{aligned}
& Y=\alpha+\beta_{1} O M P s+\beta_{2} C M P s+ \\
& +\beta_{3} I P s+\beta_{4} R S P s+\varepsilon,
\end{aligned}
$$

(1) The quantitative research technique was used to collect the designated respondents' information and conducted statistical analysis to evaluate the opinion and establish the conclusion. Information was acquired from a primary survey utilizing an organized questionnaire. The study utilized SPSS

Where $Y$-IBPP, $\alpha$-Constant, $\beta_{1 \ldots n}$ - Estimated parameters of the IBPP, $\varepsilon$ - Error term of the IBPP,

OMPs - Operation management processes, CMPs - Customer management processes, IPs Innovation processes, RSPs - Regulatory and social processes.

In addition to the measured variables, the variables such as defects in product and processes, reliability of equipment, time to resolve customers concerns, number of environmental and safety incidents, etc., also affect the IBPP, as indicated in the equation's error term $(\varepsilon)$.

The study established the following hypotheses:

$H_{1}$ : $\quad$ Measures in OMPs are used effectively and efficiently to have a meaningful and important impact on IBPP.

$\mathrm{H}_{2}$ : Measures in CMPs are used effectively and efficiently to have a meaningful and important impact on IBPP.

$H_{3}: \quad$ Measures in IPs are used effectively and efficiently to have a meaningful and important impact on IBPP.

$H_{4}: \quad$ Measures in RSPs are used effectively and efficiently to have a meaningful and important impact on IBPP.

\section{METHODOLOGY}


Table 1. Construct-wise reliability indicators

\begin{tabular}{l|c|c|c|c}
\hline \multicolumn{1}{c}{ Construct } & Cronbach's alpha & Average inter-item correlation & Observed variables & No. of items \\
\hline OMPs & 0.876 & 0.489 & VAR_8,9,10,11,12,13 & 6 \\
\hdashline CMPs & 0.741 & 0.434 & VAR_14, 15, 16 & 3 \\
IPS & 0.783 & 0.491 & VAR_17, 18, 19 & 3 \\
RSPs & 0.703 & 0.323 & VAR_20, 21,22, 23 & 4 \\
\hline Total no. of test-items & & & & 16 \\
\hline
\end{tabular}

version 23 programming to analyze and interpret information.

The study population includes all the telecom operators in Nepal and their employees. Two major operators, NT and Ncell, were the example companies as they possess more than $94 \%$ of the Nepalese telecom industry's market share. Designated respondents were the employees holding at least an officer or/and above position in their company. Using a random sampling technique, a sum of 318 accurately filled responses was acquired. The example companies had 1,850 respondents as of February 29, 2020. As Krejcie and Morgan (1970) and Bowerman et al. (2004) recommended, the example size of 318 was adequate for further analysis.

The survey questionnaire comprised 27 items and was divided into three parts. The initial part asked respondents general and demographic information, including seven questions. The subsequent part requested literature-based IBPP measures, including 16 queries. The last part requested for general IBPP and included four queries. The last two parts centered on IBPP variables, and a progression of close-ended inquiries was formed to get the required data from the respondents. All the survey items of the second and third part of the questionnaire were assessed on a six-point Likert-type scale with $1=$ strong disagreement to $6=$ strong agreement. The six-point scale was chosen to prevent middle-rating indifference.

Both online and field surveys were used to collect data. An online survey was administered to approach a total of 500 respondents using a database provided by the respective sample companies during 120-days of March-June 2020. Out of them, 152 responses were obtained and recorded. On the other hand, a total of 500 respondents were approached in a field survey. One hundred sixty-six correctly filled up responses were recorded from
182 , where 16 were refused in data recording because of incompleteness. Therefore, the study utilized a total of 318 responses.

The reliability of the IBPP measures was evaluated using Cronbach's alpha $(\alpha=0.911)$ and an inter-item coefficient $(r=0.389)$ obtained from 16 observed variables. The construct-wise analytical reliability indicators are presented in Table 1.

Table 1 showed that all constructs had strong alpha values, 0.7 or more, as suggested by Nunnally (1993). Furthermore, the constructs had an excellent average inter-item correlation coefficient and dropped in the best scope of 0.15 to 0.50 as proposed by Clark and Watson (1995). The study had a sufficient example size since the Kaiser-MeyerOlkin (KMO) value of 0.894 from 16 observed variables was more significant than an edge worth of 0.5 , as suggested by Kaiser (1974). The noteworthy value of Bartlett's test of sphericity (2519.343, df $=120, p=0.000$ ) demonstrated that the observed variables had some associations with one another. The constructs' legitimacy was evaluated through CR (composite reliability) and AVE (average variance extracted). As suggested by Hair et al. (2010), observed variable-wise standardized regression loads equal to 0.50 and more were engaged into reflection at the respective constructs for ascertaining the CR and the AVE. The construct-wise validity measures are presented in Table 2 .

Table 2. Validity measures

\begin{tabular}{l|c:c:c:c}
\hline \multirow{2}{*}{ Indicators } & \multicolumn{4}{|c}{ Constructs } \\
\cline { 2 - 5 } & OMPs & CMPs & IPs & RSPs \\
\hline CR & 0.883 & 0.761 & 0.828 & 0.745 \\
\hdashline AVE & 0.557 & 0.524 & 0.616 & 0.426 \\
\hline
\end{tabular}

Table 2 showed that all the constructs had CR values of more than 0.7 and AVE of more than 0.50, except the RSPs proposed by Fornell and Larcker (1981). Moreover, they asserted that the latent construct legitimacy is satisfactory if the AVE is 
less than 0.5, but CR is greater than 0.70. Besides, Bagozzi and Baumgartner (1994) also stated that AVE values greater than 0.4 are viewed as acceptable validity measures. Therefore, all the IBPP constructs' had good validity measures.

\section{RESULTS}

This study was the employees' assessment of the Nepalese telecom operators regarding whether the internal business process indicators were applied in an organizational performance measurement framework. To accomplish the study goals, primary data had been collected from 318 employees of NT and Ncell through an organized survey questionnaire. The employees were 259 (81.4\%) from NT and 59 (18.6\%) from Ncell. According to the example outlined, the respondents' working department was from $18.9 \%$ general administration; $34.9 \%$ account/finance; $14.8 \%$ management; $28.9 \%$ techni$\mathrm{cal} / \mathrm{IT}$; and $2.5 \%$ legal. The current working position of the employees were: $85.5 \%$ officers, $12.6 \%$ managers, and $1.9 \%$ executives. Female employees were comparatively lower than the male employees in the Nepalese telecom industry. The study captured $24.8 \%$ responses from the female employees and $75.2 \%$ from the male employees, having distinctive age groups and all seven provinces of Nepal. More than $92 \%$ of respondents had at least five years' experience in the telecommunications sector concerning their work experience years.

A standard multiple regression was carried out between IBPP as the dependent variable with OMPs, CMPs, IPs, and RSPs as independent variables. The IBPP model outline and ANOVA (analysis of variance) results are displayed in Table 3 and Table 4 , respectively. The adjusted multiple correlations were considerably different from zero $(F=71.670$, $p>.000$ ), and the set of independent variables explained $47.1 \%$ of the variation in the dependent variable. The overall model description is reported in Table 5.

Table 3. IBPP model outline

\begin{tabular}{c|c|c|c|c}
\hline Model & $\boldsymbol{R}$ & $\boldsymbol{R}$ square & $\begin{array}{c}\text { Adjusted } \boldsymbol{R} \\
\text { square }\end{array}$ & $\begin{array}{c}\text { Std. error } \\
\text { of the estimate }\end{array}$ \\
\hline & 0.691 & 0.478 & 0.471 & 0.62466 \\
\hline
\end{tabular}

Note: Predictors: (Constant), OMPs, CMPs, IPs, RSPs. Dependent variable: IBPP.

Table 4. IBPP ANOVA result

\begin{tabular}{l|c|c|c|c|c}
\hline \multicolumn{1}{c}{ Model } & $\begin{array}{c}\text { Sum of } \\
\text { squares }\end{array}$ & Df & $\begin{array}{c}\text { Mean } \\
\text { square }\end{array}$ & F & Sig. \\
\hline Regression & 111.861 & 4 & 27.965 & 71.670 & 0.000 \\
\hdashline Residual & 122.131 & 313 & 0.390 & & \\
\hdashline Total & 233.992 & 317 & & & \\
\hline
\end{tabular}

Note: Predictors: (Constant), OMPs, CMPs, IPs, RSPs. Dependent variable: IBPP.

Regression equations are:

$$
\begin{aligned}
& Y=\alpha+\beta 1 O M P S+\beta 2 C M P s+ \\
& +\beta 3 I P S+\beta 4 R S P s+\varepsilon \\
& Y=0.935+0.213 O M P s+ \\
& +0.352 C M P s+0.019 I P s+ \\
& +0.184 R S P S+\varepsilon .
\end{aligned}
$$

All the independent variables, excluding IPs, contributed significantly to the IBPP of the Nepalese telecom industry that meant the hypotheses $\mathrm{H} 1$, $\mathrm{H} 2$ and $\mathrm{H} 4$ were accepted, and $\mathrm{H} 3$ was rejected. There was no multi-collinearity problem, as the observed variance inflation factors (VIF) value

\begin{tabular}{|c|c|c|c|c|c|c|c|c|}
\hline \multirow[t]{2}{*}{ Model } & \multicolumn{2}{|c|}{$\begin{array}{c}\text { Unstandardized } \\
\text { coefficients }\end{array}$} & \multirow{2}{*}{$\begin{array}{c}\begin{array}{c}\text { Standardized } \\
\text { coefficients }\end{array} \\
\text { Beta }\end{array}$} & \multirow{2}{*}{$t$-value } & \multirow{2}{*}{ Sig. } & \multicolumn{2}{|c|}{ Collinearity statistics } & \multirow{2}{*}{$\begin{array}{l}\text { Remarks on } \\
\text { hypothesis }\end{array}$} \\
\hline & B & S.E & & & & Tolerance & VIF & \\
\hline (Constant) & 0.935 & 0.202 & & 4.619 & 0.000 & & & - \\
\hline OMPs & 0.213 & 0.056 & 0.229 & 3.803 & 0.000 & 0.461 & 2.168 & Accepted \\
\hline CMPs & 0.352 & 0.059 & 0.380 & 6.010 & 0.000 & 0.418 & 2.394 & Accepted \\
\hline IPs & 0.019 & 0.046 & 0.024 & 0.404 & 0.686 & 0.488 & 2.051 & Rejected \\
\hline RSPS & 0.184 & 0.053 & 0.175 & 3.494 & 0.001 & 0.665 & 1.504 & Accepted \\
\hline
\end{tabular}
did not exceed the threshold value of 4.0 and the tolerance less than 0.2 as recommended by Hair et al. (2010).

Table 5. IBPP regression coefficients of IBPP

Note: Dependent variable: IBPP. 


\section{DISCUSSION}

The study's literature review revealed four primary constructs to measure the IBPP. Out of them, the latent measures OMPs, CMPs, and RSPs were observed as significant contributors to the Nepalese telecom industry's IBPP. The CMPs was one of the most significant contributors to IBPP ( $\beta=0.380$, $p=0.000, \mathrm{AVE}=0.524)$ and widely understood. The OMPs stood at second $(\beta=0.229, p=0.000$, AVE $=0.557)$ and the RSPs at third $(\beta=0.175, p$ $=0.001, \mathrm{AVE}=0.426)$ while assessing the IBPP of the industry.

As earlier research observed (like Ali et al., 2010; Kaplan \& Norton, 1996, 2001; Min et al., 2016; Ndubisi, 2003), the study showed that the observed CMPs variables directly affected the IBPP, thus contributing to overall organizational efficiency. It induced as earlier studies (like Farooq \& Hussain, 2011; Flint et al., 2002; Hammer \& Champy, 1993; Hum \& Sim, 1996; Joshi, 2014; Khashman, 2019; Majumdar, 1998; Mukherjee \& Chatterjee, 2013; Sapkauskiene \& Leitoniene, 2010; Scheer et al., 2010) that OMPs were significantly associated with IBPP in the Nepalese scenario. Service industry operational excellence reduces costs, optimizes output, reduces delivery time, and improves customer satisfaction (Muazu \& Tasmin, 2017). It also reinforced Kaplan and Norton's (2001) findings that non-financial interventions related to OMPs allow managers to recognize processes essential to achieving the goals of customers and stakeholders.

Similarly, the study's outcome was also consistent with Sureshchandar and Leisten's (2005) findings that RSPs are new considerations and hold some weight affecting organizational performance. Evidence showed that the latent variables take a step forward in both strategy formulation and implementation side-by-side. The study results were also consistent with Selvam et al. (2016), where they claimed that organizational performance is a relevant construct across the globe and often used as a dependent variable. Hence, organizational efficiency is a subset of corporate success that encompasses both operational and financial outcomes.

Contrary to previous studies (Cooper et al., 1998; Kaplan \& Norton, 2001; Kyei \& Bayoh, 2017; Morris, 2013), the latent variable IPs (measuring variables such as offering innovative services, achieving excellence in research and development, and managing R\&D portfolio, etc.) were not properly utilized and understood in the Nepalese telecommunications industry. However, innovations impress consumers by translating new ideas into products/services and enhancing firm value at reasonable risk (Dotzel et al., 2013).

\section{CONCLUSION}

Organizational performance is a complex multi-dimensional construct. Any single-dimensional measures may not fully cover all aspects and provide a comprehensive understanding of organizational performance. The study coped with measuring IBPP of the Nepalese telecom industry though there are several other measures. While examining the applicability and importance of the IBPP measures in the Nepalese telecommunication's performance assessment systems, the latent measures: OMPs (with six observed variables), CMPs (with three observed variables), and RSPs (with four observed variables) were significant and influential. The latent measure IPs with three observed variables $(\beta=0.024, p>$ $0.05)$ was not properly applied and understood. While evaluating the power of the IBPP measures, the latent measure CMPs $(\beta=0.380, p<0.01)$ was the most dominant followed by OMPs $(\beta=0.229, p<0.01)$, and RSPs $(\beta=0.175, p<0.01)$ respectively.

The actual power of organizational success is not determined by the dependence on accounting-based performance metrics alone. This study identified the value of using IBPP on organizational performance in the Nepalese scenario's managerial decision-making process. Therefore, non-financial performance measures (like internal business processes) complement financial assessments as short-term indicators of progress towards long-term goals and provide employees with relevant feedback not available from the accounting measurements. Hence, the study supports to prove Spitzer's (2007) adage that 
says 'when performance measurement is done right, both the organization itself and its people will be impacted positively'.

Earlier studies showed that various performance appraisal models had been applied all around the globe. But in Nepal's case, none of the companies appears to be explicitly using the non-financial performance measures. Therefore, this study attempted to identify the non-financial measures in the IBPP of the Nepalese Telecom Industry. It leads to a better understanding and analytical approach in organizational performance to telecommunications services. It also can create more opportunities for developing more optimized systems for managing processes, improving employees' performance, making managerial decisions, and enhancing the overall effectiveness of the organization's services. It is believed that the study would provide helpful guidance for understanding key drivers and offer valuable information on strategic areas of performance measurement for the Nepalese telecom industry.

\section{AUTHOR CONTRIBUTIONS}

Conceptualization: Rewan Kumar Dahal.

Data curation: Rewan Kumar Dahal.

Formal analysis: Rewan Kumar Dahal.

Investigation: Rewan Kumar Dahal.

Methodology: Rewan Kumar Dahal.

Project administration: Rewan Kumar Dahal.

Software: Rewan Kumar Dahal.

Supervision: Rewan Kumar Dahal.

Validation: Rewan Kumar Dahal.

Visualization: Rewan Kumar Dahal.

Writing - original draft: Rewan Kumar Dahal.

Writing - review \& editing: Rewan Kumar Dahal.

\section{REFERENCES}

1. Abernethy, M. A., Bouwens, J., \& Lent, L. (2013). The role of performance measures in the intertemporal decisions of business unit managers. Contemporary Accounting Research, 30(3), 925-961. https://doi.org/10.1111/j.19113846.2012.01178.x

2. Ahmad, K., \& Zabri, S. M. (2016). The application of non-financial performance measurement in Malaysian manufacturing firms. Procedia Economics and Finance, 35, 476-484. https:// doi.org/10.1016/S2212 5671(16)00059-9

3. Ali, J. F., Ali, I., Rehman, K., Yilmaz, A. K., Safwan, N., \& Afzal, H. (2010). Determinants of consumer retention in the cellular industry of Pakistan. African Journal of Business Management, 4(12), 2402-2408. Retrieved from https://academicjournals.org/ article/article1380787868_Ali\%20 et\%20al.pdf

4. Amir, A., \& Lev, B. (1996). Valuerelevance of non-financial information: the wireless communications industry. Journal of Accounting and Economics, 22(13), 3-30. https://doi.org/10.1016/ S0165-4101(96)00430-2

5. Atkinson, A. A., Balakrishnan, R., Booth, P., Cote, J. M., Groot, T., Malmi, T., Roberts, H., Enrico, Uliana, \& Wu, A. (1997). New directions in management accounting research. Journal of Management Accounting Research, 9(1), 79-108. Retrieved from https://research.vu.nl/en/publications/new-directions-in-management-accounting-research

6. Atkinson, A. A., Kaplan, R. S. Matsumura, E. M., Young, S.
M., \& Kumar, G. A. (2014).

Management Accounting Information for Decision Making and Strategy Execution (6 ${ }^{\text {th }} \mathrm{ed}$.). New Delhi: Pearson Education, Inc.

7. Bagozzi, R. P., \& Baumgartner, H. (1994). The evaluation of structural equation models and hypothesis testing. In R. P. Bagozzi (Ed.). Principles of Marketing Research (pp. 386-422). Cambridge: Blackwell.

8. Bowerman, B. L., O'Connell, R. T., \& Orris, J. B. (2004). Essential business statistics ( $3^{\text {rd }}$ ed.). New York: McGraw Hill.

9. Clark, L. A., \& Watson, D. (1995). Constructing validity: Basic issues in objective scale development. Psychological Assessment, 7(3), 309319. https://doi.org/10.1037/10403590.7.3.309 
10. Cooper, R. G., Edgett, S. J., \& Kleinschmidt, E. J. (1998). Best practices for managing research and development portfolios. Research Technology Management, 41(4), 20-33. http://dx.doi.org/10.1080/0 8956308.1998.11671219

11. Dotzel, T., Shankar, V., \& Berry, L. L. (2013). Service innovativeness and firm value. Journal of Marketing Research, 50(2), 259276. http://dx.doi.org/10.1509/ jmr.10.0426

12. Farooq, A., \& Hussain, Z. (2011). Balanced scorecard perspective on change and performance: A study of selected Indian companies. Procedia - Social and Behavioral Sciences, 24, 754-768. https://doi. org/10.1016/j.sbspro.2011.09.043

13. Flint, D. J., Woodruff, R. B., \& Gardial, S. F. (2002). Exploring the phenomenon of customers' desired value change in a business-to-business context. Journal of Marketing, 66(4), 102117. https://doi.org/10.1509/ jmkg.66.4.102.18517

14. Fornell, C., \& Larcker, D. F. (1981). Evaluating structural equation models with unobservable variables and measurement error. Journal of Marketing Research, 18(1), 39-50. https://doi.org/10.2307/3151312

15. Franco-Santos, M., Kennerley, M., Micheli, P., Martinez, V., Mason, S., Marr, B., Gray, D., \& Neely, A. (2007). Towards a definition of a business performance measurement system. International Journal of Operations and Production Management, 27(8), 784-801.

16. Hair, J. F., Black, W. C., Babin, B. J., \& Anderson, R. E. (2010). Multivariate data analysis: A global perspective ( $7^{\text {th }}$ ed.). London: Prentice-Hall.

17. Hammer, M., \& Champy, J. (1993). Reengineering the corporation: A manifesto for business revolution. New York: Harper Business.

18. Hum, S. H., \& Sim, H-H. (1996). Time-based competition: Literature review and implications for modelling. International Journal of Operations and Production Management,
16(1), 75-90. https://doi. org/10.1108/01443579610106373

19. Josee, V. M., Gongera, G. E., \& Anyika, E. (2016). Critical analysis of adoption of modern technology and its impact on the financial performance of telecommunication industry in Rwanda. Social and Basic Sciences Research Review, 4(9), 166-176.

20. Joshi, S. (2014). Customer experience management: An exploratory study on the parameters affecting customer experience for cellular mobile services of a telecom company. Procedia - Social and Behavioral Sciences, 133, 392-399. https://doi. org/10.1016/j.sbspro.2014.04.206

21. Kaiser, H. F. (1974). An index of factorial simplicity. Psychometrika, 39, 31-36. https://psycnet.apa.org/ doi/10.1007/BF02291575

22. Kaplan, R. S., \& Norton, D. P. (1992). The balanced scorecard measures that drive performance. Harvard Business Review, 70(1), 71-79. Retrieved from http:// planuba.orientaronline.com.ar/ wp-content/uploads/2010/03/ harvard-business-review-kaplannorton-the-balanced-scorecardmeasures-that-drive-performance. pdf

23. Kaplan, R. S., \& Norton, D. P. (1993). Putting the balanced scorecard to work. Harvard Business Review, 71(5), 134-147. Retrieved from https://www. ucipfg.com/Repositorio/GSPM/ Cursos/SPOA_GSPM_02/PBSWHBROPEE6.pdf

24. Kaplan, R. S., \& Norton, D. P. (1996). Using the balanced scorecard as strategic management system. Harvard Business Review, 74(1), 75-85. Retrieved from https://hbr.org/2007/07/using-thebalanced-scorecard-as-a-strategicmanagement-system

25. Kaplan, R. S., \& Norton, D. P. (2001). Transforming the balanced scorecard from performance measurement to strategic management: Part I. Accounting Horizons, 15, 87-104. Retrieved from http://citeseerx.ist.psu.edu/ viewdoc/download?doi=10.1.1.33 $5.2005 \& \mathrm{rep}=$ rep $1 \&$ type $=$ pdf
26. Khanmohammadi, M., Mohammadi, M., \& Mehdizadeh, N. (2015). The feasibility of implementing the balanced scorecard - case study: Nationwide provincial telecom companies. International Business Research, 8(8), 118-128. http://dx.doi.org/10.5539/ ibr.v8n8p118

27. Khashman, A. M. (2019). The effect of business process reengineering on organizational performance: The mediating role of information and communications technology. International Journal of Business and Management, 14(9), 132-149. https://doi.org/10.5539/ijbm. v14n9p132

28. Krejcie, R., \& Morgan, D. (1970). Determining sample size for research activities. Educational and Psychological Measurement, 30(3), 607-610. https://journals.sagepub.com/ doi/10.1177/001316447003000308

29. Kyei, D. A., \& Bayoh, A. T. M. (2017). Innovation and customer retention in the Ghanaian telecommunication industry. International Journal of Innovation, 5(2), 1-15. https://doi.org/10.5585/ iji.v5i2.154

30. Majumdar, S. K. (1998). On the utilization of resources: Perspectives from the U.S. telecommunications industry. Strategic Management Journal, 19(9), 809-831. Retrieved from https://www.jstor.org/ stable/3094087

31. Melville, N., Kraemer, K., \& Gurbaxani, V. (2004). Review: information technology and organizational performance: an integrative model of IT business value. Management Information System, 28(2), 283-322. https://doi. org/10.2307/25148636

32. Min, S., Zhang, X., Kim, N., \& Srivastava, R. K. (2016). Customer acquisition and retention spending: An analytical model and empirical investigation in wireless telecommunications markets. Journal of Marketing Research, 53(5), 728-744. https:// doi.org/10.1509/jmr.14.0170

33. Morris, L. (2013). How to innovate: The innovation process. Innovation 
management. Retrieved from https://innovationmanagement. se/2013/08/08/how-to-innovatethe-innovation-process/

34. Muazu, M. H., \& Tasmin, R (2017). Operational excellence in manufacturing, service and the oil \& gas: The sectorial definitional constructs and risk management implication. Path of Science, 3(9), 3001-3008. https://doi. org/10.22178/pos.26-4

35. Mukherjee, D., \& Chatterjee, M. (2013). Business process reengineering and customer satisfaction with reference to Indian telecommunication sector. Journal of Academia and Industrial Research, 2(2), 126-133. Retrieved from https://www.semanticscholar. org/paper/Business-ProcessReengineering-and-Customerwith-to-Mukherjee-Chatterjee/1 122974be291059cbf3003557edcc850126f1f54

36. Ndubisi, N. O. (2003). Service quality: Understanding customer perception and reaction, and its impact on business. International Journal of Business, 5(2), 7-19. http://dx.doi.org/10.22146/gamaijb.5407

37. Nepal Telecommunication Authority. (2020). MIS Report. Retrieved from https://nepalindata. com/media/resources/items/15/ bMIS-2076-Falgun.pdf
38. Nunnally, J. C. (1993). Psychometric theory ( $3^{\text {rd }}$ ed.). New York: McGraw Hill.

39. Sapkauskiene, A., \& Leitoniene, S. (2010). The concept of time-based competition in the context of management theory. Engineering Economics, 21(2), 205-213.

40. Scheer, L. K., Miao, C. F., \& Garrett, J. (2010). The effects of supplier capabilities on industrial customers' loyalty: The role of dependence. Journal of the Academy of Marketing Science, 38, 90-104. https://doi.org/10.1007/ s11747-008-0129-6

41. Selvam, M., Gayathri, J., Vasanth, V., Lingaraja, K., \& Marxiaoli, S. (2016). Determinants of firm performance: A subjective model. International Journal of Social Science Studies, 4(7), 90-100. https://doi.org/10.11114/ijsss. v4i7.1662

42. Silver, E. A. (2004). Process management instead of operations management. Manufacturing and Service Operations Management, 6(4), 273279. https://doi.org/10.1287/ msom.1040.0055

43. Spitzer, D. R. (2007). Transforming performance measurement: Rethinking the way we measure and drive organizational success. New York: AMACOM.
44. Sullivan, T. (2001). Scorecards ease businesses balancing act. InfoWorld, 23(2), 32-32.

45. Sureshchandar, G. S., \& Leisten, R. (2005). Holistic scorecard: Strategic performance measurement and management in the software industry. Measuring Business Excellence, 9(2), 12-29. https://doi. org/10.1108/13683040510602849

46. Venkatram, R., \& Zhu, X. (2012). An analysis of factors influencing the telecommunication industry growth - A case study of China and India (Master's thesis). Blekinge Institute of Technology, Sweden. Retrieved from https:// www.diva-portal.org/smash/get/ diva2:829355/fulltext01.pdf

47. Yeniyurt, S. (2003). A literature review and integrative performance measurement framework for multinational companies. Marketing Intelligence \& Planning, 21(3), 134-142. https://doi. org/10.1108/02634500310474957

48. Zuriekat, M., Salameh, R., \& Alrawashdeh, S. (2011). Participation in performance measurement system and level of satisfaction. International Journal of Business and Social Science, 2(8), 159-169. Retrieved from https://docplayer. net/5336983-Participation-inperformance-measurementsystems-and-level-of-satisfaction. html 